\title{
Elementary Pre-Service Teachers' Metaphorical Perceptions Regarding Life Sciences
}

\begin{tabular}{|c|c|}
\hline \multicolumn{2}{|c|}{$\begin{array}{l}{ }^{a} \text { Anadolu University, Faculty of Education, Eskişehir/Turkey } \\
{ }^{\mathrm{b}} \text { Uşak University, Faculty of Education, Uşak/Turkey }\end{array}$} \\
\hline Article Info & Abstract \\
\hline DOI: 10.14812/cufej.2014.001 & $\begin{array}{l}\text { The aim of this study is to determine the metaphors elementary pre-service teachers' } \\
\text { used regarding Life Sciences. This study was conducted with the participation of } 130\end{array}$ \\
\hline Article history: & teacher candidates from elementary education in Faculty of Education at Muğla \\
\hline Received 29 June 2012 & University. A questionnaire consisted of open ended questions has been created to \\
\hline Revised 12 December 2013 & determine the views of teacher candidates regarding Life Sciences. The questions are \\
\hline Accepted 01 February 2014 & $\begin{array}{l}\text { generally similar to "Life Sciences is like ..... ; because ......". Teacher candidates' views } \\
\text { regarding Life Sciences has been analyzed with content analysis technique. After the }\end{array}$ \\
\hline $\begin{array}{l}\text { Keywords: } \\
\text { Pre-service teachers, } \\
\text { Life Sciences, } \\
\text { Metaphor. }\end{array}$ & $\begin{array}{l}\text { study, it's been seen that teachers created } 49 \text { metaphors such as addressing } \\
\text { requirements, an indispensable element, connected to each other, guiding, extensive } \\
\text { content, creating curiosity and excitement, creating awareness, real life experience, } \\
\text { source of energy, problem solving, and negative effect. As a result, it has been found } \\
\text { out that teacher candidates are aware of the importance of Life Sciences. However, } \\
\text { there are some teacher candidates having negative thoughts regarding Life Sciences. }\end{array}$ \\
\hline
\end{tabular}

\section{Introduction}

Life Sciences is one of the most important subjects of elementary school education. While constituting the starting point for Turkish language, Mathematics, Art, Music and Physical Education subjects within the first three years of elementary school, it establishes the basis for Social Studies as well as Science and Technology subjects in the fourth year. As the teachers of this subject, elementary school teachers play an important role for the Life Sciences subject to achieve its goals. There is no doubt that the pre-service training that elementary school teachers receive is essential in achieving the goals of Life Sciences subject, since elementary school teachers are trained in such a manner as to be able to teach all subjects included in the first four years of elementary school education. In this respect, it is important to determine the perceptions of elementary teachers regarding Life Sciences as one of the basic subjects in the elementary school curriculum.

Metaphors enable individuals to perceive a phenomenon like another phenomenon through shifting the mind from a certain way of comprehension to another (Saban, 2009). Due to shifting from one phenomenon to another, metaphors could be considered as a bridge between two phenomena (Cortazzi \& Jin, 1999).

Metaphors ensure that abstract concepts are explained through establishing relationships with concrete concepts and contribute to developing creative thinking skills of individuals. As individuals use metaphors in identifying emotions and thoughts of both theirs and others, metaphorical structures display the ways they perceive the world and themselves (Girmen, 2007). It means that individuals

*Corresponding author:mgulteki@gmail.com 
express their social realities through metaphorical idioms. In this respect, metaphors play an important role in identifying "the real" (Lakoff \& Johnson, 2005).

In general, metaphor is a means of expressing a conceptual structure through another one. This structure, known as the structural metaphor, consists of the source concept, which involves the metaphorical explanations made in order to understand the other concept and the target concept that is understood with the help of these explanations. Therefore, the source concept is the concept that enables the target concept to be understood. For instance, in the life is a journey statement, life is the target concept and journey is the source concept (Kövecses, 2010).

Metaphoric structures are used by individuals continuously in daily life. Individuals make use of metaphors in explaining events and thoughts emerging in familial or professional relationships to others as well as revealing negative thoughts along with appreciated or approved situations (Zanotto, Cameron \& Cavalcanti, 2008). Moreover, metaphors play important roles in development of disciplines in various fields of interest (Cortazzi \& Jin, 1999).

Metaphors are one of the tools that could be used in determining elementary school teachers' perceptions about Life Sciences. According to Yildirim \& Simsek (2011), metaphors are tools that enable individuals to understand their environments and nature, to derive meanings through certain interpretations from an objective reality that seems meaningless, and to attach meaning to experience. Metaphors, which are used to make abstract thoughts and concepts concrete, have been subjected to recent studies in the field of education. In education, metaphors are most commonly used for predicting hypotheses on concepts such as teachers (Alacapinar, 2011; Cerit, 2008; Celikten, 2006; Yildirim, Unal \& Celik, 2011), teaching (Greves, 2005), learning, student (Aydin \& Pehlivan, 2010; Saban, 2009), school (Aydogdu, 2008; Saban, 2008), and the elementary curriculum (Tasdemir \& Tasdemir, 2011). There are also studies on how certain subjects are perceived (Aydin \& Eser-Unaldi, 2010; Guven \& Guven, 2009; Kilic \& Guven, 2009; Yasar \& Gurdogan Bayir, 2010). Among these, the only study on determining perceptions of elementary school students about Life Sciences is that of Kilic \& Guven (2009). There have been no studies found on metaphors to determine pre-service teachers' perceptions about Life Sciences in particular.

Perceptions of pre-service teachers about the subject they would teach are important variables in the implementation of the relevant curriculum. Accordingly, the perceptions of elementary pre-service teachers, who would be responsible for teaching various subjects, about Life Sciences would affect the implementation of the subject. In this respect, metaphors have important functions in revealing the perceptions of elementary pre-service teachers about the Life Sciences. Therefore, the aim of this study is to determine metaphorical perceptions of pre-service teachers in the Elementary Education Program in the Education Faculty about Life Sciences.

\section{Method}

\section{Research Design}

In this study, which has been designed in a descriptive pattern, metaphors produced by elementary pre-service teachers about Life Sciences were collected through an open-ended survey and conceptual categories were structured according to the metaphors produced.

\section{Participants}

In qualitatively patterned studies, the participants are identified through a purposeful sampling procedure (Creswell, 2005). The criterion sampling method among purposive sampling methods was chosen for the study. In criterion sampling procedure, the entities who meet the predetermined criteria are included in the sample (Büyüköztürk, Kllıç-Çakmak, Akgün, Karadeniz \& Demirel, 2012). There were 
two criteria in determining the sampling: voluntary participation and enrollment in the Life Science Teaching course. In this respect, the study was conducted with 130 pre-service teachers (77 female, 53 male) studying in their third or fourth years in the Elementary Teaching Program at Mugla University, Faculty of Education and their subsequent enrollment in the "Life Science Teaching" course.

\section{Instrument}

Open-ended survey is used as the data collection instrument. In the questionnaire, preservice teachers were requested to complete the following sentence: "Considering the objectives of Life Sciences course, I think Life Sciences is similar to/is like. ; because, .."

\section{Data Analysis}

A content analysis among the qualitative research methods was used for the analysis of the data. Metaphors produced by the elementary pre-service teachers about Life Sciences were analyzed through the processes of determining metaphors, compiling sample metaphor images, developing categories, and providing reliability.

\section{Results}

The results indicated that elementary pre-service teachers produced 49 metaphors and the following categories were developed about Life Sciences: addressing requirements, an indispensable element, connected to each other, guiding, extensive content, creating curiosity and excitement, creating awareness, real life experience, source of energy, problem solving, and negative effect. The "addressing requirements" category consisted of cellar ( $f: 3)$, bag (f:6), farmers' market, market car and piggy bank ( $f: 5)$ metaphors. The category of "an indispensable element" involved lungs (f:4), bread ( $f: 2$ ), oxygen $(f: 4)$, engine, and water ( $f: 3)$ metaphors. The "Connected to each other" category consisted of metaphors such as tree ( $f: 4)$, Russian nesting doll, chain ( $f: 3)$ and puzzle. "Guiding" category contained guide ( $f: 3)$, teacher ( $f: 5)$, life coach, road, torch ( $f: 6)$, bus, sun and mirror ( $f: 5)$ metaphors. The category of "extensive content" involved metaphors such as rainbow, earth (f:6), sky, life cycle and red lentil-mint soup metaphors. The "Creating curiosity and excitement" category consisted of amusement park, ocean and educational games metaphors. "Creating awareness" category involved autobiography and explorer ( $f: 3)$ metaphors. The category of "real life experience" contained movies (f:2), miniature, novel (f:4), cinema ( $f: 4)$ and 3D glasses metaphors. "Source of energy" category consisted of antibiotics ( $f: 5)$, fish and vitamin (f:5) metaphors. "Problem solving" category was composed of wrench (f:5), Swiss knife (f:3), toolbox (f:5), service (f:4), arm floats, sledgehammer and first aid kit (f:6) metaphors. "Negative effect" category involved labyrinth (f:4) and factory metaphors.

\section{Discussion, Conclusion \& Implementation}

Through the "addressing requirements" category, elementary pre-service teachers attempted to draw attention to the fact that Life Sciences is a necessary and required subject in the elementary curriculum, while metaphors produced in the "indispensable element" category indicated Life Sciences as an indispensable subject for attaining certain skills and knowledge. Metaphors in the "connected to each other" category emphasized that the spiral principal should be considered in preparing the curriculum content. Metaphors produced in the "guiding" category revealed pre-service teachers' emphasis on the guiding aspect of Life Sciences. Metaphors produced by pre-service teachers in the "extensive content" category reflects that Life Sciences had an extensive content comprised of various knowledge. Through metaphors produced in the "creating curiosity and excitement" category, preservice teachers mentioned that this subject and the activities carried out during classes attracted students' attention and created curiosity. Similarly, pre-service teachers produced metaphors in the "creating awareness" category indicating that Life Sciences enabled individuals to better recognize 
themselves and their learning process, while through metaphors in the "real life experience" category, they emphasized the relevance of Life Sciences to daily life. Metaphors in the "source of energy" category were indicators that pre-service teachers established a connection between Life Sciences and being energetic or active. While pre-service teachers produced metaphors in the "problem solving" category reflecting their perception of Life Sciences as a subject attaining knowledge, skills and qualifications for problem solving, they drew attention to the complex structure of the course content through the metaphors they produced in the "negative effect" category.

Recommendations are as follows:

- Perceptions about Life Sciences could also be determined through different methods. These studies would highlight the importance of Life Sciences.

- Using metaphors could be effective to determine student requirements by teachers within the teaching/learning process. Teachers could be guided accordingly.

- The reasons for the negative perceptions of elementary pre-service teachers about Life Sciences could be investigated and measures could be taken for overcoming this negativity.

- Metaphors to be produced by elementary pre-service teachers for subjects other than Life Sciences could be determined. 


\section{Sınıf Öğretmeni Adaylarının Hayat Bilgisi Dersine iliş̧kin Metaforik Algıları}

\begin{tabular}{|c|c|}
\hline \multicolumn{2}{|c|}{ 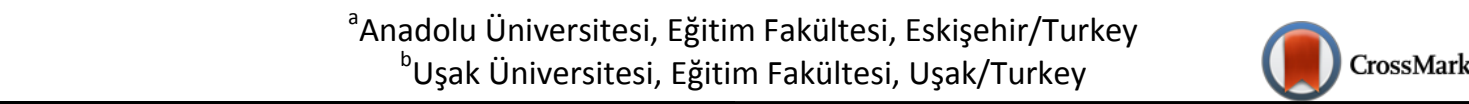 } \\
\hline Makele Bilgisi & Öz \\
\hline DOI: $10.14812 /$ cufej.2014.001 & $\begin{array}{l}\text { Bu araştırmanın amacı, sınıf öğretmeni adaylarının Hayat Bilgisi dersine ilişkin } \\
\text { kullandıkları metaforları belirlemektir. Araştırma, Muğla Üniversitesi Eğitim Fakültesi }\end{array}$ \\
\hline Makale geçmişi: & İlköğretim Bölümü Sınıf Öğretmenliği Programında 3. ve 4. sınıfta öğrenim gören 130 \\
\hline Geliş $\quad 29$ Haziran 2012 & öğretmen adayı ile gerçekleştirilmiştir. Araştırma verileri, araştırmaya katılan öğretmen \\
\hline Düzeltme 12 Aralık 2013 & adaylarının Hayat Bilgisi dersine ilişkin sahip oldukları düşünceleri ortaya çıkarmak \\
\hline Kabul $\quad 01$ Şubat 2014 & $\begin{array}{l}\text { amacıyla hazırlanan açık uçlu bir anket formu ile toplanmıştır. Anket formunda } \\
\text { öğretmen adaylarından "Hayat Bilgisi dersinin amaçları düşünüldüğüne; Hayat Bilgisi }\end{array}$ \\
\hline $\begin{array}{l}\text { Anahtar kelimeler: } \\
\text { Öğretmen adayları, } \\
\text { Hayat bilgisi, } \\
\text { Metafor. }\end{array}$ & $\begin{array}{l}\text { dersini..........................benzetirim; çünkü..........................." cümlesini tamamlamaları } \\
\text { istenmiştir. Öğretmen adaylarının Hayat Bilgisi dersine ilişkin düşünceleri içerik analizi } \\
\text { tekniği ile çözümlenmiştir. Araştırma sonucunda öğretmen adaylarının Hayat Bilgisi } \\
\text { dersine ilişkin olarak toplam } 49 \text { metafor ürettikleri görülmüş; Hayat Bilgisi dersine } \\
\text { ilişkin olarak ihtiyaç karşılayan, vazgeçilmez bir öğe, birbiriyle bağlantılı, yol gösterici, } \\
\text { geniş bir içerik, heyecan ve merak uyandıran, farkındalık kazandıran, gerçek yaşam } \\
\text { deneyimi, enerji kaynağı, sorun çözücü ve olumsuz etki kategorileri oluşturulmuştur. } \\
\text { Sonuç olarak sınıf öğretmeni adaylarının Hayat Bilgisi dersinin öneminin farkında } \\
\text { oldukları; ancak ders konusunda olumsuz düşünceye sahip öğretmen adaylarının da } \\
\text { bulunduğu ortaya çıkmıştır. }\end{array}$ \\
\hline
\end{tabular}

\section{Giriş}

Hayat Bilgisi, ilköğretimin önemli derslerinden birisidir. Bu ders, ilköğretimin ilk üç yılında Türkçe, Matematik, Resim, Müzik, Beden Eğitimi derslerinin hareket noktasını oluştururken, dördüncü yılında ise Fen ve Teknoloji ile Sosyal Bilgiler derslerinin de temelini oluşturmaktadır. 2005 yılında uygulamaya konulan Hayat Bilgisi dersi öğretim programında genel olarak yaşama ilişkin konular hakkında düşüncesi olan, yakın çevresini tanıyarak çevresine uyum sağlayabilen ve günlük yaşamda kullanabileceği kadar bilgi ile donanmış mutlu bireylerin yetiştirilmesi amaçlanmaktadır. Bu bağlamda etkinliklerin, öğrencilerin sosyal, kültürel, zihinsel ve kişisel gelişimlerine yardım edecek, temel yaşama becerilerini ve olumlu kişisel nitelikleri kazandıracak biçimde tasarlanması istenmektedir. Buradan hareketle Hayat Bilgisi dersinin amaçlarına ulaşabilmesinde bu dersi veren sınıf öğretmenlerine önemli görevler düşmektedir. Kuşkusuz Hayat Bilgisi dersinin amaçlarına ulaşmasında sınıf öğretmenlerinin hizmet öncesinde aldıkları eğitimin önemi büyüktür. Çünkü sınıf öğretmeni adayları ilköğretimin ilk beş sınıfında yer alan derslerin tümünün öğretimini yapabilecek biçimde yetiştirilmektedir. Bu yönüyle, sınıf öğretmeni adaylarının ilköğretimde yer alan ve temel derslerden biri olan Hayat Bilgisi dersine ilişkin algılarının belirlenmesi önemlidir.

Öğretmen adaylarının Hayat Bilgisi dersine ilişkin algılarının belirlenmesinde kullanılabilecek araçlardan biri metaforlardır. Yıldırım ve Şimşek (2011)'e göre metaforlar insanın doğayı ve çevresini anlamasına, anlamsız gibi görünen nesnel gerçeklikten belirli yorumlar yoluyla anlamlar çıkarmasına ve yaşantı ve deneyime anlam kazandırmaya olanak sağlayan araçlarıdır. Metaforlar, bir bireyin zihninin

*Yazar: mgulteki@gmail.com 
belli bir kavrayış biçiminden başka bir kavrayış biçimine doğru yönelmesini sağlayarak o bireyin belli bir olguyu başka bir olgu olarak görmesine olanak tanırlar (Saban, 2009). Bu bağlamda, bir olgudan başka bir olguya yönelmeden dolayı metaforlar, iki olgu arasındaki ilişkiyi kuran köprü olarak görülebilirler (Cortazzi ve Jin, 1999).

Metaforlar, soyut kavramların somut kavramlarla ilişkilendirilerek açıklanmasını sağlar ve bu sayede bireyin yaratıcı düşünme becerisini geliştirmesine katkıda bulunurlar. Bireyler metaforları, hem kendi duygu ve düşüncelerini hem de karşılarındakilerin duygu ve düşüncelerini tanımlarken kullandıklarından, metaforik yapılar, bireylerin dünyayı ve kendilerini algılama biçimlerini göstermektedir (Girmen, 2007). Başka bir deyişle bireyler, sosyal gerçekliklerini metaforik terimlerle ifade ederler. Bu bağlamda metaforlar 'gerçek olan şey'in belirlenmesinde çok önemli bir rol oynar (Lakoff ve Johnson, 2005).

Genel olarak metafor, bir kavram yapısını başka bir kavram yapısıyla ifade etme biçimidir. Kavramsal metafor olarak adlandırılan bu yapı, öteki kavramı anlayabilmek için yapılan metaforik açıklamaları içeren kaynak kavram ve bu açıklamalar sayesinde anlaşılan hedef kavramdan oluşmaktadır. Buna göre, kaynak kavram hedef kavramın anlaşılabilmesine olanak sağlayan kavramdır. Örneğin, yaşam bir seyahattir cümlesine bakıldığında, yaşam sözcüğü hedef kavram; seyahat sözcüğü ise kaynak kavramdır (Kövecses, 2010).

Metaforik yapılar, bireyler tarafından günlük yaşamda sürekli olarak kullanılmaktadır. Bireyler, aile içi ilişkilerde ve iş dünyasında karşılaşılan olay ve düşünceleri öteki insanlara anlatmada ve hoşa giden, kabul gören durumların yanısıra, negatif düşünceleri ortaya çıkarmada metaforlardan yararlanırlar (Zanotto, Cameron ve Cavalcanti, 2008). Bunların ötesinde metaforlar, değişik alanlardaki disiplinlerin gelişmesinde de önemli rol oynar (Cortazzi ve Jin, 1999).

Soyut düşünce ve kavramların somutlaştırılmasında kullanılan metaforlar, son yıllarda eğitim alanında gerçekleştirilen araştırmalarda sıklıkla kullanılmaktadır. Metaforlar eğitim alanında en yaygın biçimde öğretmen (Alacapınar, 2011; Cerit, 2008; Çelikten, 2006; Yıldırım, Ünal ve Çelik, 2011), öğretim (Greves, 2005), öğrenme, öğrenci (Aydın ve Pehlivan, 2010; Saban, 2009), okul (Aydoğdu, 2008; Saban, 2008), ilköğretim programı (Taşdemir ve Taşdemir, 2011) kavramlarına yönelik varsayımları açıklama ve ortaya çıkarmada kullanılmaktadır. Bunun yanısıra, bazı derslerin nasıl algılandığına yönelik araştırmalara da rastlanmaktadır (Aydın ve Eser-Ünaldı, 2010; Güven ve Güven, 2009; Kılıç ve Güven, 2009; Yaşar ve Gürdoğan Bayır, 2010). Bu araştırmalar incelendiğinde, ilköğretim öğrencilerinin Hayat Bilgisi dersine ilişkin algılarını ortaya koymayı amaçlayan araştırma olarak yalnızca Kılıç ve Güven'in (2009) çalışması bulunmakta, özellikle öğretmen adaylarının Hayat Bilgisi dersine ilişkin algılarını ortaya koyan metafor çalışmasına rastlanılmadığı anlaşılmaktadır.

Öğretmen adaylarının, öğretimini yapacakları derse yönelik algıSı, o dersin programını başarıyla uygulamalarında önemli bir değişkendir. Bu açıdan birçok alanın öğretimini yapmakla sorumlu olan sınıf öğretmeni adaylarının Hayat Bilgisi dersine yönelik algıları; o dersin uygulamalarını etkileyecektir. Dolayısıyla sınıf öğretmeni adaylarının Hayat Bilgisi dersine ilişkin algılarını ortaya çıkarmada metaforlar önemli işleve sahiptir. Cortazzi ve Jin (1999) metaforların öğretme-öğrenme sürecinde kullanılmasıyla, öğrenenlerin öğrendikleri konuya, anahtar kavramlara ilişkin farkındalığının artacağını ve öğretmenlerin de kendi öğrenme deneyimlerini öğrencilerine yansıtabilmelerine ve alanda uzmanlaşmalarına olanak sağlayacağını belirtmiştir. Bu nedenle gerçekleştirilen bu çalışmada sınıf öğretmeni adaylarının Hayat Bilgisi dersine yönelik görüşleri, metaforlar yoluyla belirlenmeye çalışılmıştır.

Bu bağlamda araştırmanın amacı, Eğitim Fakültesi İlköğretim Bölümü Sınıf Öğretmenliği Programı öğretmen adaylarının Hayat Bilgisi dersine ilişkin metaforik algılarını belirlemektir. Bu genel amaç doğrultusunda araştırmada şu sorulara yanıt aranmıştır: 
1. Öğretmen adaylarının Hayat Bilgisi dersine ilişkin sahip oldukları metaforlar nelerdir?

2. Öğretmen adaylarının Hayat Bilgisi dersine ilişkin sahip oldukları metaforların oluşturduğu kavramsal kategoriler nelerdir?

\section{Yöntem}

\section{Araştırma Modeli}

Betimsel nitelikte tasarlanan bu araştırmada, sınıf öğretmeni adaylarının Hayat Bilgisi dersine ilişkin ürettikleri metaforlar, açık uçlu anket yoluyla toplanmış ve üretilen metaforlardan yola çıkılarak kavramsal kategoriler oluşturulmuştur.

\section{Katılımcılar}

Nitel olarak desenlenen araştırmalarda katılımcılar, amaçlı örnekleme yöntemi ile belirlenmektedir (Creswell, 2005). Araştırmada amaçlı örnekleme yöntemlerinden ölçüt örnekleme yöntemi benimsenmiştir. Ölçüt örneklemede örneklem için belirlenen ölçütü karşılayan birimler (nesneler, olaylar, vb.) örnekleme alınırlar (Büyüköztürk, Kılıç Çakmak, Akgün, Karadeniz ve Demirel, 2012). Buna göre katıımcıların belirlenmesinde araştırmaya gönüllü katılım ve Hayat Bilgisi Öğretimi dersini almış olma biçiminde iki temel ölçüt dikkate alınmışır. Katılımcıların kişisel özelliklerine ilişkin bilgiler Tablo 1 'de sunulmuştur.

Tablo 1.

Katılımcıların Kişisel Özellikleri.

\begin{tabular}{llll}
\hline \multicolumn{2}{l}{ Kişisel Özellikler } & $\begin{array}{l}\text { Sayı } \\
\text { (N) }\end{array}$ & $\begin{array}{l}\text { Yüzde } \\
\text { (\%) }\end{array}$ \\
\hline \multicolumn{2}{c}{ Cinsiyet } & & \\
& Kız & 77 & 59.2 \\
& Erkek & 53 & 40.8 \\
\hline Sınıf & & \\
& 3. sınıf & 92 & 70.2 \\
& 4. sınıf & 38 & 29.8 \\
\hline Öğrenim Türü & & \\
$\quad$ Normal Öğretim & 60 & 46.2 \\
$\quad$ ikinci Öğretim & 70 & 53.8 \\
\hline TOPLAM & 130 & 100 \\
\hline
\end{tabular}

\section{Veri Toplama Aracı}

Araştırma verileri, araştırmacılar tarafından oluşturulan açık uçlu anket formu ile toplanmıştır. Anket formu iki bölümden oluşmuştur. Anket formunun ilk bölümünde kişisel bilgilere yer verilmiş, ikinci bölümde ise sınıf öğretmeni adaylarının Hayat Bilgisi dersine ilişkin algılarını belirlemek amacıyla "Hayat Bilgisi dersinin amaçları düşünüldüğünde; Hayat Bilgisi dersini..............................benzetirim; çünkü..........................." cümlesini tamamlamaları ve Hayat Bilgisi dersini tek bir kavram ile ilişkilendirerek bunun nedenini açıklamaları istenmiştir.

\section{Verilerin Toplanması}

Araştırma verileri Muğla Üniversitesi Eğitim Fakültesi Sınıf Öğretmenliği Programı 3. ve 4. sınıfta öğrenim gören ve 'Hayat Bilgisi Öğretimi' dersini alan 130 sınıf öğretmeni adayından toplanmıştır. 


\section{Verilerin Analizi}

Verilerin çözümlenmesinde, nitel araştırma yöntemlerinden içerik analizi kullanılmıştır. İçerik analizinde amaç, birbirine benzeyen verileri belirli kavramlar ve temalar çerçevesinde bir araya getirmek ve bunları okuyucunun anlayabileceği bir biçimde düzenleyerek yorumlamaktır (Yıldırım ve Şimşek, 2011). Sınıf öğretmeni adaylarının geliştirdikleri Hayat Bilgisi dersine ilişkin metaforların analizi, metaforların belirlenmesi, örnek metafor imgelerinin derlenmesi, kategori geliştirme ve güvenirlik sağlama süreçleriyle gerçekleştirilmiştir.

Metaforların belirlenmesi aşamasında öncelikle, öğretmen adaylarından toplanan anket formları ayrıntılı biçimde incelenmiş ve Hayat Bilgisi dersine ilişkin metaforun belirgin bir biçimde ifade edilmediği formlar ayıklanmıştır. Bununla birlikte, boş bırakılan formlar ile metafor oluşturduğu halde, sözkonusu metafora ilişkin mantıklı bir gerekçe sunmayan öğretmen adaylarının formları da araştırma kapsamı dışında tutulmuştur. Yapılan incelemeler sonucunda, 160 formdan 30'u sözü edilen nedenlerden dolayı elenerek, 130 form araştırma kapsamına alınmıştır. Araştırmada toplam 49 metafor üretilmiştir. Üretilen metaforlar, alfabetik sıraya göre listelenmiştir.

Örnek metafor imgelerinin derlenmesi aşamasında, sınıf öğretmeni adayları tarafından üretilen her metafor için, o metaforu en iyi biçimde ifade eden metafor imgeleri seçilmiş ve her metafora ilişkin örnek imgeyi oluşturan geçici bir liste yapılmıştır. Kategori geliştirme aşamasında sınıf öğretmeni adayları tarafından geliştirilen metaforlar "metaforun konusu", "metaforun kaynağı" ve "metaforun konusu ve kaynağı arasındaki ilişki" göz önünde bulundurularak kategorilere ayrılmıştır. Bu kategorilerde benzer özellikleri içeren metaforlara yer verilmiştir. Araştırmada 49 metaforu içeren toplam 11 kavramsal kategori oluşturulmuştur. Son olarak güvenirliğin sağlanması aşamasında ise, nitel veri analizinde gerçekleştiren adımlar ayrıntılarıyla betimlenmiştir. Ayrıca, oluşturulan kategoriler, bu kategorilere ilişkin metaforlar ve bununla ilgili metafor imgeleri, araştırmacılar dışında farklı beş uzmana verilmiştir. Uzmanlar, yapılan analizleri ve alıntıları karşılaştırmış, yeniden kategorileştirmiştir. Daha sonra, uzmanlar, görüş ayrılığı bulunan kategorilere ilişkin bir araya gelmiş ve görüş birliğine ulaşılmıştır. Bunun sonucunda kategorilere son biçimi verilmiştir.

\section{Bulgular}

Bu bölümde öncelikle sınıf öğretmeni adaylarının Hayat Bilgisi dersine ilişkin ürettikleri metaforlar sunulmuş; daha sonra oluşturulan kavramsal kategorilere yer verilmiştir. Kategoriler açıklanırken, öğretmen adaylarından alıntılar yapılarak örnek metafor imgelerine yer verilmiştir. Araştırma kapsamında öğretmen adaylarının ürettikleri metaforlar Tablo 2'de verilmiştir.

Tablo 2'de görüldüğü gibi, sınıf öğretmeni adaylarının Hayat Bilgisi dersine ilişkin toplam 49 metafor ürettikleri belirlenmiştir. Üretilen metaforlardan kimisi canlı varlıklarken, kimisi de cansız varlıklardır. Öğretmen adaylarının ürettikleri metaforlardan yola çıkılarak oluşturulan kavramsal kategoriler Şekil 1'de verilmiştir.

Şekil 1'de görüldüğü gibi, öğretmen adaylarının Hayat Bilgisi dersine ilişkin ürettikleri metaforlardan yola çıkarak oluşturulan kavramsal kategoriler "ihtiyaç karşılayan", "vazgeçilmez bir öğe", "birbiriyle bağlantıı", "yol gösterici", "geniş bir içerik", "heyecan ve merak uyandıran", "farkındalık kazandıran", "gerçek yaşam deneyimi", "enerji kaynağı", "sorun çözücü" ve "olumsuz etki" başlıkları altında ele alınmıştır. "ihtiyaç karşılayan" kategorisine ilişkin metaforlar Şekil 2'de gösterilmiştir. 
Tablo 2.

Sınıf Öğretmeni Adaylarının Hayat Bilgisi Dersine Ilişskin Ürettikleri Metaforlar

\begin{tabular}{|c|c|c|c|c|c|}
\hline No & Metafor & No & Metafor & No & Metafor \\
\hline 1 & Ağaç & 18 & İlkyardım çantası & 35 & Eğitsel oyun \\
\hline 2 & Akciğer & 19 & İngiliz anahtarı & 36 & Öğretmen \\
\hline 3 & Alet çantası & 20 & İsviçre çakısı & 37 & Pazar arabası \\
\hline 4 & Antibiyotik & 21 & Kaşif & 38 & Roman \\
\hline 5 & Ayna & 22 & Kılavuz & 39 & Sinema \\
\hline 6 & Balık & 23 & Kumbara & 40 & Su \\
\hline 7 & Balyoz & 24 & Labirent & 41 & Tamirhane \\
\hline 8 & Çanta & 25 & Lunapark & 42 & Üç boyutlu gözlük \\
\hline 9 & Dünya & 26 & Malzeme deposu & 43 & Vitamin \\
\hline 10 & Ekmek & 27 & Matruşka & 44 & Yapboz \\
\hline 11 & Ezogelin çorbası & 28 & Köy pazarı & 45 & Yaşam döngüsü \\
\hline 12 & Fabrika & 29 & Minyatür & 46 & Yaşam koçu \\
\hline 13 & Fener & 30 & Motor & 47 & Yol \\
\hline 14 & Film & 31 & Oksijen & 48 & Yüzme kolluğu \\
\hline 15 & Gökkuşağı & 32 & Okyanus/Deniz & 49 & Zincir \\
\hline 16 & Gökyüzü & 33 & Otobiyografi & & \\
\hline 17 & Güneş & 34 & Otobüs & & \\
\hline
\end{tabular}

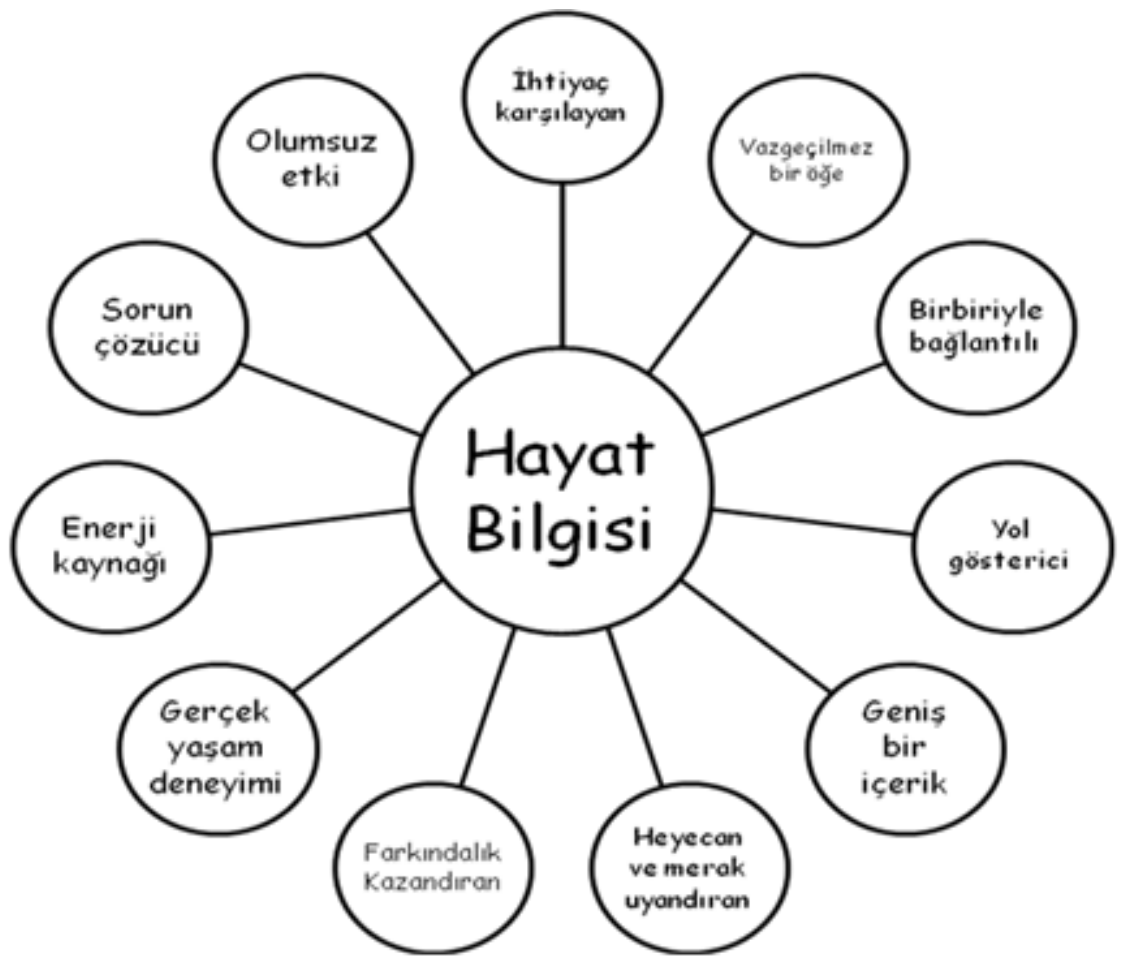

Şekil 1. Hayat Bilgisi Dersine Yönelik Oluşturulan Kategoriler. 


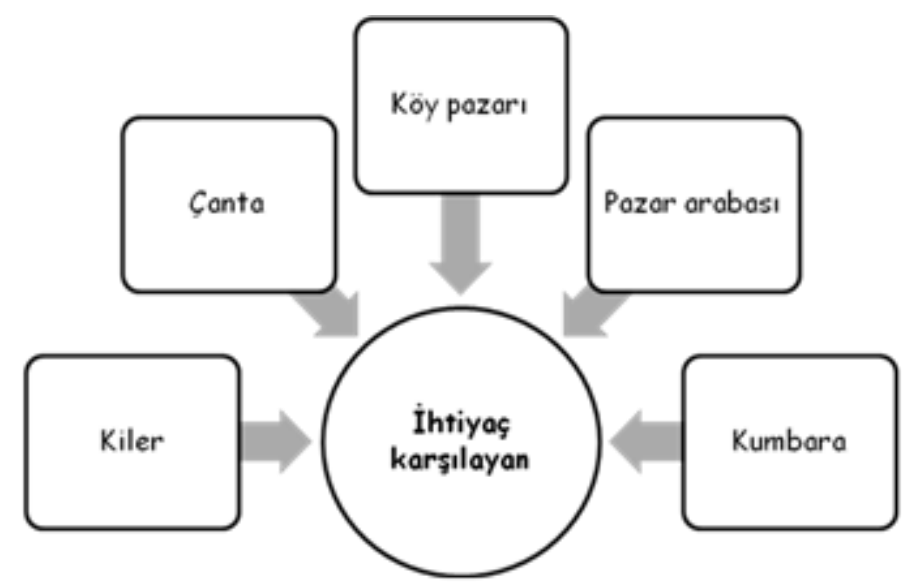

Şekil 2. Ihtiyaç Karşılayan Kategorisi.

Şekil 2'de görüldüğü gibi, "ihtiyaç karşılayan" kategorisini kiler (f:3), çanta (f:6), köy pazarı, pazar arabası ve kumbara (f:5) metaforları oluşturmuştur. Bu metafordan kiler metaforu 3, çanta metaforu 6 ve kumbara metaforu 5 öğretmen adayı tarafından kullanılmış; diğer metaforlar birer kez tekrar edilmiştir. Hayat Bilgisi dersini çantaya benzeten öğretmen adaylarından biri görüşünü "Hayat Bilgisi çanta gibidir. Gün içinde ihtiyaç duyduğumuz eşyalarımız çantamızdadır. Okulda öğrenmemiz gereken bilgileri de Hayat Bilgisi dersi ile öğreniriz" biçimde belirterek Hayat Bilgisi dersinin, ihtiyaç duyulan gerekli bilgilerden oluştuğunu vurgulamıştır. Hayat bilgisi dersini kilere benzeten bir öğretmen adayının görüşü ise "Kilerde bize lazım olan şeyler vardır. Ihtiyaç duyduğumuzda çıkarıp kullanırız. (...). Hayat Bilgisi dersinde öğrendiklerimizi de gerçek hayatta ihtiyaç duyduğumuzda kullanırız. Bu bakımdan Hayat Bilgisi dersi evdeki kilere benzer" biçimindedir.

Öğretmen adaylarının görüşleri bağlamında oluşturulan “vazgeçilmez bir öğe” kategorisi Şekil 3’te gösterilmiştir.

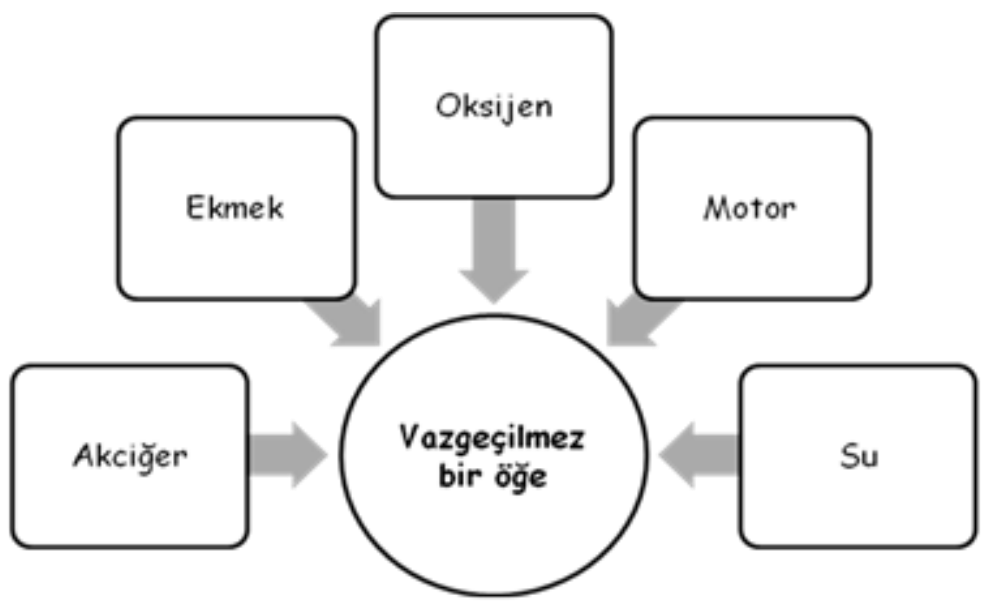

Şekil 3. Vazgeçilmez Bir Öğe Kategorisi.

Şekil 3'te görüldüğü gibi, "vazgeçilmez bir öğe" kategorisini akciğer (f:4), ekmek (f:2), oksijen (f:4), motor ve su (f:3) metaforları oluşturmuştur. Bu metafordan akciğer metaforu 4, ekmek metaforu 2, oksijen metaforu 4 ve su metaforu 3 öğretmen adayı tarafından kullanılmıştır. Hayat Bilgisi dersine ilişkin ekmek metaforunu oluşturan öğretmen adaylarından biri görüşünü "Ekmek yemezsek doymayız, sofradan aç kalkarız. Sofrada ekmek ne kadar gerekliyse ilköğretimde Hayat Bilgisi dersi o kadar 
gereklidir" biçiminde belirterek, Hayat Bilgisi dersinin gerekliliğine vurgu yapmıştır. Yine, öğretmen adaylarından birinin görüşü "Motor arabanın temelini oluşturan en önemli bileşendir. Hayat Bilgisi dersi de ilköğretimin temelini oluşturur. Bu bakımdan motora benzer" biçimindedir. Öğretmen adaylarının görüşleri bağlamında oluşturulan "birbiriyle bağlantılı" kategorisi Şekil 4'te gösterilmiştir.

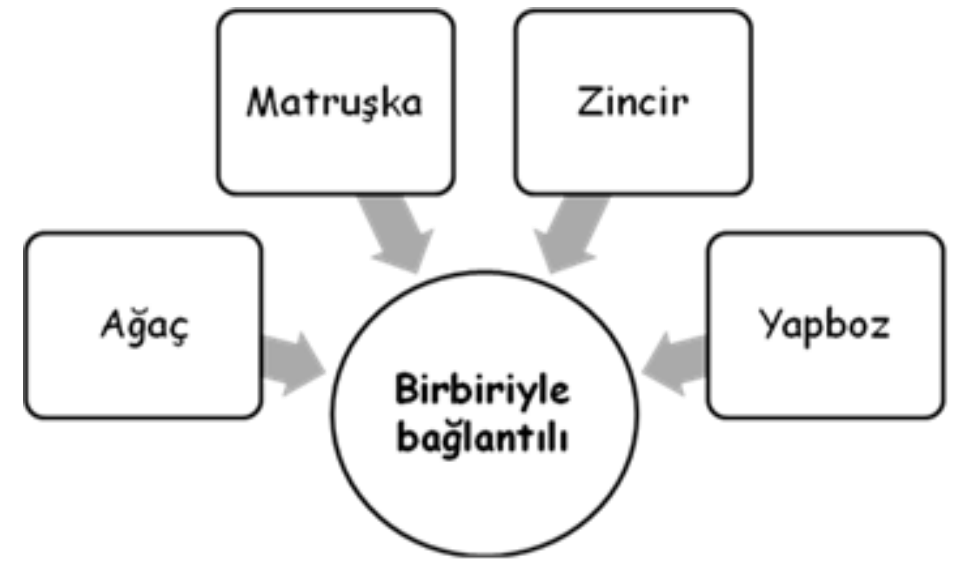

Şekil 4. Birbiriyle Bağlantılı Kategorisi.

Şekil 4'te görüldüğü gibi "birbiriyle bağlantılı" kategorisi ağaç (f:4), matruşka, zincir (f:3) ve yapboz metaforlarından oluşmaktadır. Bu metaforlardan ağaç metaforu 4, zincir metaforu 3öğretmen adayı tarafından kullanılmış; diğer metaforlar birer kez tekrar edilmiştir. Hayat Bilgisi dersini zincire benzeten öğretmen adayı "Hayat Bilgisi dersinin konuları, bir zincir gibi birbiriyle bağlantılı ve iç içedir (...)." biçiminde görüş belirterek Hayat Bilgisi dersinin temaları, konuları ve üniteleri arasındaki ilişkiye dikkat çekmiştir. Bu ders ile matruşka metaforunu ilişkilendiren bir öğretmen adayı ise "Hayat Bilgisi dersi matruşkaya benzer. Çünkü aynı matruşka gibi ünite başlıkları ve konular birbiriyle bağlantılı ve iç içedir. Her bir ünite birbirini kapsar ve üniteler birbiriyle iç içedir" biçiminde görüş bildirerek Hayat Bilgisi dersi öğretim programının içeriğine vurgu yapmıştır.

Öğretmen adaylarının görüşlerine dayalı olarak oluşturulan "yol gösterici” kategorisi Şekil 5'te gösterilmiştir.

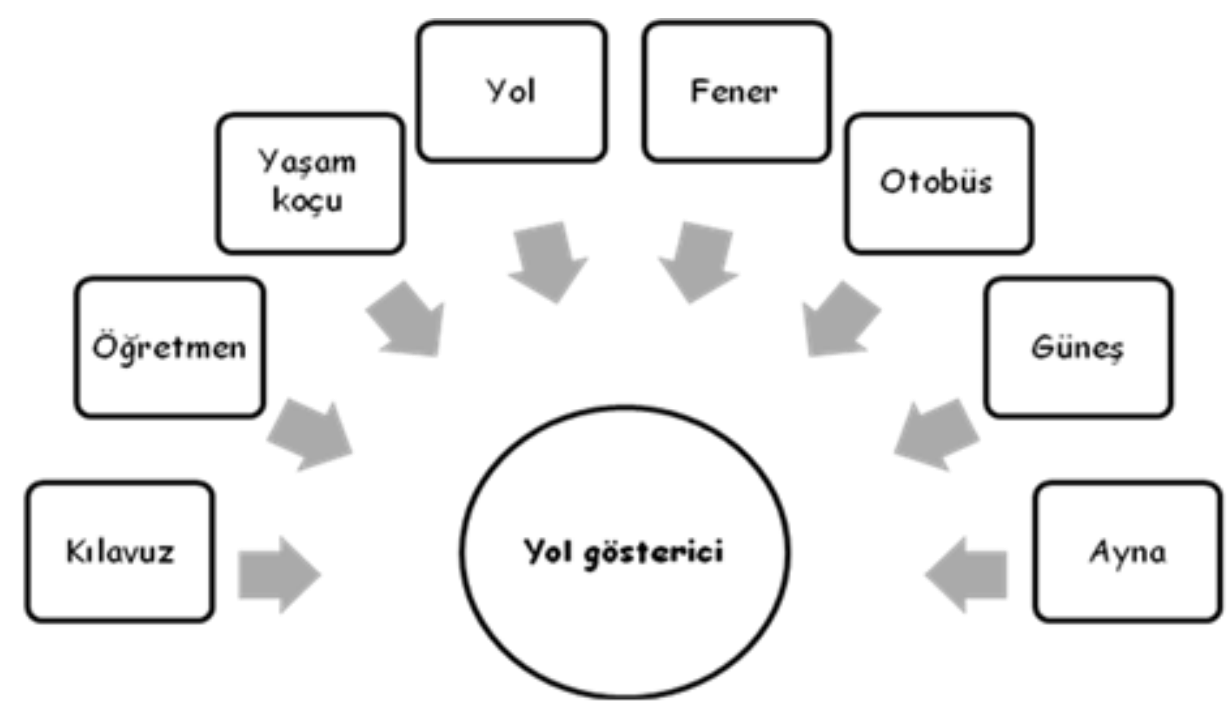

Şekil 5. Yol Gösterici Kategorisi. 
Şekil 5'te görüldüğü gibi "yol gösterici" kategorisi kılavuz (f:3), öğretmen (f:5), yaşam koçu, yol, fener (f:6), otobüs, güneş ve ayna (f:5) metaforlarından oluşmaktadır. Bu metaforlardan kılavuz metaforu 3, öğretmen metaforu 5, fener metaforu 6 ve ayna metaforu 5 öğretmen adayı tarafından kullanılmış; diğer metaforlar birer kez tekrar edilmiştir. Hayat Bilgisi dersini yaşam koçuna benzeten sınıf öğretmeni adayı "Bu ders yaşam koçunun bireye rehberlik etmesi gibi hayatımızı nasıl sürdüreceğimizi, nasıl bir insan, toplumda nasıl bir kişi olacağımızı, kendimizi tanımamızı, empati kurabilmemizi, yaşamı anlamlı ve kaliteli kılmamızı öğretir" biçiminde görüş belirtirken; bu dersi kılavuzla ilişkilendiren başka bir öğretmen adayı ise "Hayat Bilgisi dersi kılavuz gibi nasıl yaşamamız gerektiğini, çevremize nasıl uyum sağlamamız gerektiğini ve insanlarla nasıl iletişim kurabileceğimizi öğretir, gösterir" biçiminde görüş bildirmiştir. Öğretmen adaylarının görüşlerine dayalı olarak oluşturulan "geniş bir içerik" kategorisi Şekil 6'da gösterilmiştir.

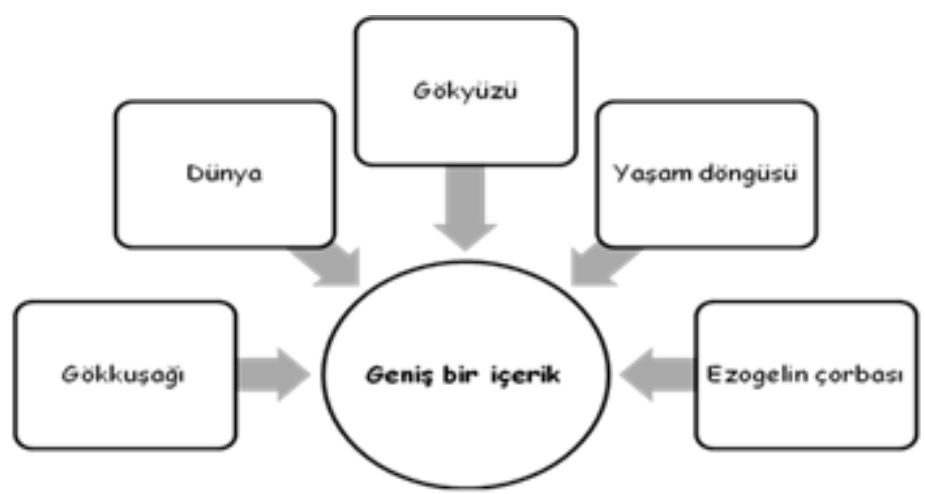

Şekil 6. Geniş Bir Içerik Kategorisi.

Şekil 6'da görüldüğü gibi "geniş bir içerik" kategorisi gökkuşağı, dünya (f:6), gökyüzü, yaşam döngüsü ve ezogelin çorbası metaforlarından oluşmaktadır. Bu metaforlardan dünya metaforu 6 öğretmen adayı tarafından kullanılmış; diğerleri birer kez tekrar edilmiştir.

Hayat Bilgisi dersini gökkuşağı ile ilişkilendiren öğretmen adayı "Gökkuşağındaki renklerin çeşitliliği gibi Hayat Bilgisi dersinde de çeşitli konular vardır. Bu ders hayatın her yönünü anlatan hayatın içindeki farklı farklı olayları konu edindiği için tıpkı gökkuşağına benzer" biçiminde görüş bildirmiştir. Bir başka öğretmen adayı ise "Ezogelin çorbası fakir bir kızın evde olan farklı malzemeleri suya koyup kaynatmasıyla ortaya çıkmış doyurucu ve lezzetli bir çorbadır. Iç̧inde her şeyden vardır. Hayat Bilgisi dersinde birçok farklı konu vardır" biçiminde görüş belirterek Hayat Bilgisi dersini ezogelin çorbasıyla ilişkilendirmiş ve bu dersin içeriğinin çeşitliliğine vurgu yapmıştır. Öğretmen adaylarının görüşlerine dayalı olarak oluşturulan "heyecan ve merak uyandıran" kategorisi Şekil 7'de gösterilmiştir.

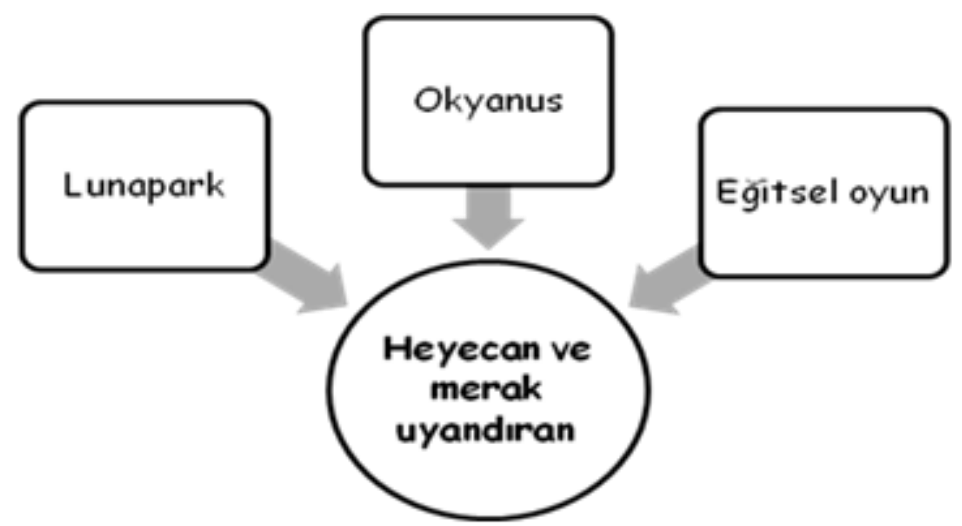

Şekil 7. Heyecan ve Merak Uyandıran Kategorisi. 
Şekil 7'de görüldüğü gibi "heyecan ve merak uyandıran" kategorisi lunapark, okyanus ve eğitsel oyun metaforlarından oluşmaktadır. Bu metaforlar öğretmen adayları tarafından birer kez kullanılmıştır. Hayat Bilgisi dersini lunaparka benzeten öğretmen adayı, görüşünü "Lunaparka giden çocuk nasıl mutlu oluyorsa, Hayat Bilgisi dersi de öğrenciye mutluluk verir. Onu heyecanlandırır, meraklandırır" biçiminde açıklamıştır. Hayat Bilgisi dersini okyanusa benzeten öğretmen adayı ise "(...) insan denize girdiğinde nasıl farklı bir boyuta girerse, farklı bir alemle karşılaşırsa Hayat Bilgisi dersi de öyledir. Her bir konu farklı bir aleme götürür öğrenciyi. Yeni yeni deniz canlılarıyla tanışır gibi yeni konular öğrenirsin. Hayat Bilgisinin konuları aynı denizde yaşayan canlılar gibi ilgi ve merak uyandırır öğrencide” biçiminde görüş belirtmiştir. Öğretmen adaylarının görüşlerine dayalı olarak oluşturulan "farkındalık kazandıran" kategorisi Şekil 8'de gösterilmiştir.

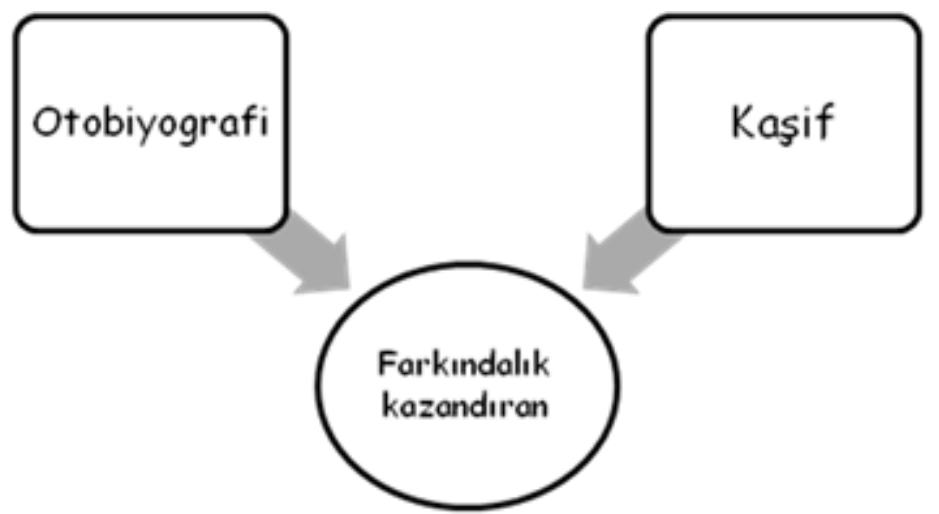

Şekil 8. Farkındalık Kazandıran Kategorisi.

Şekil 8'de görüldüğü gibi "farkındalık kazandıran" kategorisi otobiyografi ve kâşif (f:3) metaforlarından oluşmaktadır. Bu metaforlardan kaşif metaforu 3 öğretmen adayı tarafından kullanılmış; diğer metafor bir kez tekrar edilmiştir. Hayat Bilgisi dersini otobiyografiye benzeten öğretmen adayı "Hayat Bilgisi dersi otobiyografi yazmak gibi kişinin kendi hayatını anlamasına, keşfetmesine, anlatmasına olanak sağlar. Kendi hayatı hakkında farkındalık kazanır" biçiminde görüş bildirirken; bu dersi kâşife benzeten öğretmen adayı "Bu ders sayesinde aynı bir kaşif gibi hayatı, kendimizi ve çevremizi öğreniriz. Bu ders etrafımızı keşfetmemize yardımcı olur" biçiminde görüş belirtmiştir. Öğretmen adaylarının görüşlerine dayalı olarak oluşturulan "gerçek yaşam deneyimi" kategorisi Şekil 9'da gösterilmiştir.

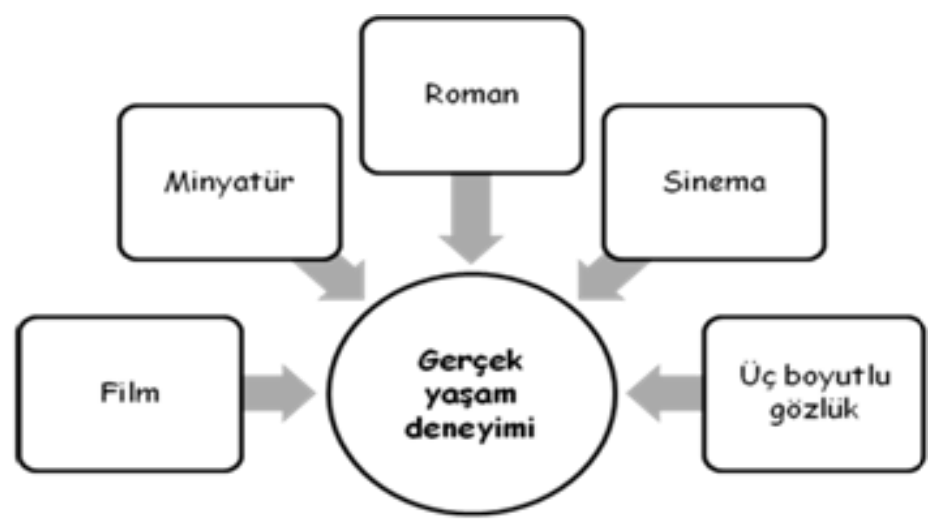

Şekil 9. Gerçek Yaşam Deneyimi Kategorisi.

Şekil 9'da görüldüğü gibi "gerçek yaşam deneyimi" kategorisi film (f:2), minyatür, roman (f:4), sinema (f:4) ve üç boyutlu gözlük metaforlarından oluşmaktadır. Bu metaforlardan film metaforu 2, roman metaforu 4, sinema metaforu 4 öğretmen adayı tarafından kullanılmış; diğer metaforlar birer kez tekrar 
edilmiştir. Hayat Bilgisi dersini üç boyutlu gözlük ile ilişkilendiren öğretmen adayı, görüşünü "Çocuklar hayatı Hayat Bilgisi dersi ile gerçek boyutlarıyla düşünüp, hayal ederek öğrenirler. Hayat Bilgisi dersinde kendilerinin hayatın bir parçası olduğunu ve hayatı sadece karşıdan izlemeyip her an o anlardan birinde gibi hissederler. Aynı 3 boyutlu gözlük taktığımızda sanki filmin içindeymiş gibi hissetmemiz gibi" biçiminde belirtmiştir. Bu dersi minyatüre benzeten öğretmen adayı ise "Hayat Bilgisi dersi gerçek yaşamın minyatürü gibi bireyi yaşama hazırlar. Bu ders konusunu gerçek yaşamdan alır" biçiminde görüş belirtmiştir. Öğretmen adaylarının görüşleri bağlamında oluşturulan "enerji kaynağı" kategorisi Şekil 10 'da gösterilmiştir.

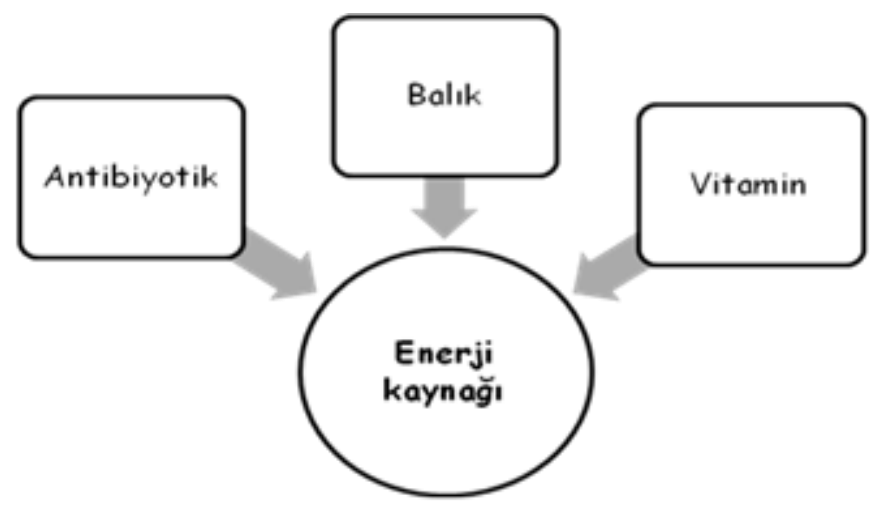

Şekil 10. Enerji Kaynağı Kategorisi.

Şekil 10’da görüldüğü gibi "enerji kaynağı” kategorisi antibiyotik (f:5), balık, ve vitamin (f:5) metaforlarından oluşmaktadır. Bu metaforlardan antibiyotik metaforu 5, vitamin metaforu 5 öğretmen adayı tarafından kullanılmış; diğer metaforlar birer kez tekrar edilmiştir. Hayat Bilgisi dersini balığa benzeten öğretmen adayı "Balıkta zekayı güçlendiren protein ve vitaminler bulunmakta, Hayat Bilgisi dersinde de iyi bir öğrenci olmamızı sağlayan bilgi ve beceriler kazanılmaktadır" biçiminde görüş bildirmiştir. Yine, bu dersi vitamin ile ilişkilendiren başka bir öğretmen adayının görüşü ise, "Hayat bilgisi dersi aynı vitamin gibi öğrencinin hayata ilişkin yanlış bildiklerini düzeltir, onarır. Onu doğru ve gerçek bilgilerle donatır" biçimindedir. Öğretmen adaylarının görüşlerine dayalı olarak oluşturulan "sorun çözücü" kategorisi Şekil 11'de gösterilmiştir.

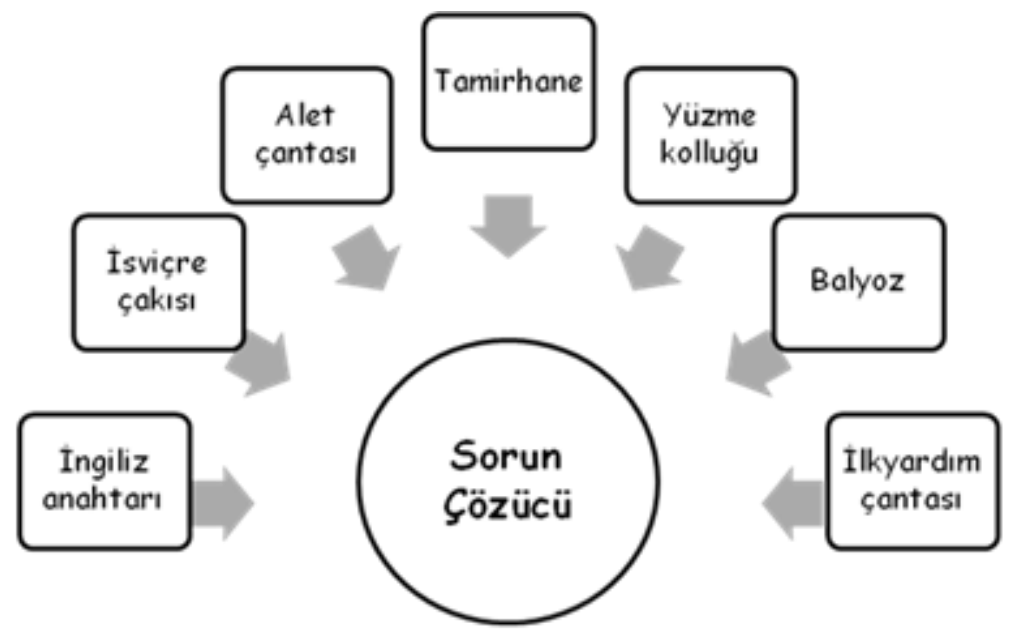

Şekil 11. Sorun Çözücü Kategorisi.

Şekil 11'de görüldüğü gibi "sorun çözücü" kategorisi Ingiliz anahtarı (f:5), İsviçre çakısı (f:3), alet çantası (f:5), tamirhane (f:4), yüzme kolluğu, balyoz ve ilkyardım çantası (f:6) metaforlarından oluşmaktadır. Bu metaforlardan İngiliz anahtarı metaforu 5, İsviçre çakısı metafor 3, alet çantası metafor 
5, tamirhane metafor 4, ilkyardım çantası metaforu 6 öğretmen adayı tarafından kullanılmış; diğer metaforlar bir kez tekrar edilmiştir. Hayat Bilgisi dersi ile İngiliz anahtarı arasında bağ kuran öğretmen adayı "Ingiliz anahtarının her vidayı açabilmesi gibi Hayat Bilgisi dersi de her soruna karşı çözüm önerileri üretmemizi sağlayan beceriler kazandırır" biçiminde görüş belirtmiştir. Hayat Bilgisi dersini İsviçre çakısına benzeten öğretmen adayı ise görüşünü "Iş̧imize yarayan, hayatımızı kolaylaştıran birçok araç Isviçre çakısında toplanmıştır (...). Hayat Bilgisi dersi de İsviçre çakısı gibi günlük hayatla baş edebilmemizi sağlayan çok yönlü bir derstir" biçiminde dile getirmiştir. Öğretmen adaylarının görüşlerine dayalı olarak oluşturulan "olumsuz etki" kategorisi Şekil 12'de gösterilmiştir.

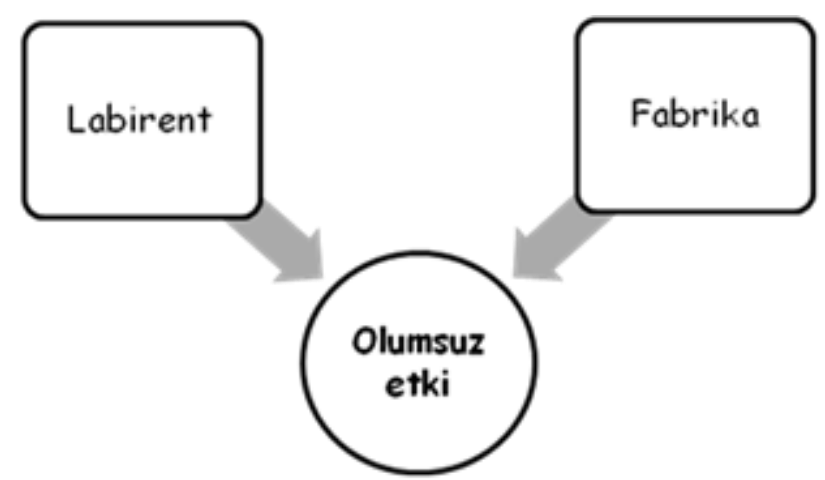

Şekil 12. Olumsuz Etki Kategorisi.

Şekil 12'de görüldüğü gibi "olumsuz etki" kategorisi labirent (f:4) ve fabrika metaforlarından oluşmaktadır. Bu metaforlardan labirent metaforu 4 öğretmen adayı tarafından kullanılmış; diğer metafor bir kez tekrar edilmiştir. Hayat Bilgisi dersini labirente benzeten öğretmen adayı "Hayat bilgisi dersi labirent gibidir. Görünüşte işin içinden çıkılacak bir derse benzer fakat zaman geçtikçe çıkışı bulmak zorlaşır" biçiminde görüş bildirirken; bu dersi fabrikaya benzeten bir başka öğretmen adayı "Hayat Bilgisi dersinin amacı tek tip insan yetiştirmektir. Fabrikada da tek tip nesneler üretilmektedir. Bu ikisinin amacı da aynıdır. Bu yüzden Hayat Bilgisi dersi, fabrikayı anımsatır bana” biçiminde görüşünü dile getirmiştir.

\section{Sonuç, Tartışma ve Öneriler}

Eğitim Fakültesi İlköğretim Bölümü Sınıf Öğretmenliği Programı öğretmen adaylarının Hayat Bilgisi dersine ilişkin algılarını belirlemeyi amaçlayan bu araştırmada toplam 49 metafor üretildiği görülmüştür. Öğretmen adaylarının ürettikleri bu metaforlarla Hayat Bilgisi dersinin değişik yönlerine vurgu yaptıkları, bu konudaki görüşlerinin genellikle olumlu olduğu ancak olumsuz kimi görüşlerin de ortaya çıktığı sonucuna ulaşılmıştır.

Araştırma bulgularına göre Hayat Bilgisi dersine ilişkin ihtiyaç karşılayan, vazgeçilmez bir öğe, birbiriyle bağlantılı, yol gösterici, geniş bir içerik, heyecan ve merak uyandıran, farkındalık kazandıran, gerçek yaşam deneyimi, enerji kaynağı, sorun çözücü ve olumsuz etki kavramsal kategorileri oluşturulmuştur.

Öğretmen adayları ihtiyaç karşılayan kategorisinde ürettikleri metaforlarla, Hayat Bilgisi dersinin ilköğretimde gerekli ve ihtiyaç duyulan bir ders olmasına dikkat çektikleri; vazgeçilmez bir öğe kategorisinde ürettikleri metaforlarla Hayat Bilgisi dersinin kimi bilgi ve becerileri kazanma ve donanımları edinmede olmazsa olmaz nitelikte bir ders olduğunu ortaya koydukları belirlenmiştir. Birbiriyle bağlantılı kategorisinde ürettikleri metaforlarla, program içeriği hazırlanırken sarmallık ilkesinin göz önünde bulundurulduğu vurguladıkları, yol gösterici kategorisinde ürettikleri metaforlarla Hayat Bilgisi dersinin yönlendirici özelliğine vurgu yaptıkları sonucuna ulaşılmıştır. Öğretmen adaylarının geniş bir içerik kategorisinde Hayat Bilgisi dersinin kapsamının geniş olduğunu, gerekli ve çeşitli bilgilerden oluştuğunu ifade ettikleri ortaya çıkarken; heyecan ve merak uyandıran kategorisinde bu dersin ve 
dersteki etkinliklerin öğrencilerin ilgilisi çekici, merak uyandırıı nitelikte tasarlandıklarını belirttikleri görülmüştür. Yine, öğretmen adayları farkındalık kazandıran kategorisinde ürettikleri metaforlarla, Hayat Bilgisi dersinin kişinin kendisini, öğrenme özelliklerini ve öğrenme sürecini daha iyi tanımasına olanak sağladığını belirtirken; gerçek yaşam deneyimi kategorisinde ürettikleri metaforlarla Hayat Bilgisi dersinin güncel yaşamla ilişkili olduğunu vurguladıkları belirlenmiştir. Enerji kaynağı kategorisine ilişkin üretilen metaforlar, öğretmen adaylarının Hayat Bilgisi dersini enerjik, zinde olmayla ilişkilendirdiklerinin bir göstergesidir. Öğretmen adaylarının sorun çözücü kategorisinde ürettikleri metaforlar, Hayat Bilgisi dersini sorun çözme becerilerinin kazandırılmasına yönelik bilgi, beceri ve donanımların kazandırıldığı bir ders olarak gördüklerinin kanıtı iken; olumsuz etki kategorisinde dersin içeriğinin karmaşık bir yapıda olduğuna dikkat çektikleri görülmektedir.

Araştırmada elde edilen sonuçları destekleyen bazı araştırma bulgularına rastlanılmıştır. Bunlardan ilki Kılıç ve Güven (2009) tarafından gerçekleştirilen araştırmadır. Illköğretim öğrencilerinin Hayat Bilgisi dersine ilişkin ürettikleri metaforları ortaya koymayı amaçlayan araştırmada, üretilen metaforlardan yola çıkılarak ışık, öğretmen, bilgi, aile, güç veren, davranışlar, iletişim aracı, bitki, çevre, hayatla ilişkili ve ana madde olmak üzere toplam 11 kavramsal kategori oluşturulmuştur. Bunlardan "bilgi", "güç veren", "hayatla ilişkili" ve "ana madde" kategorileri, bu araştırma kapsamında oluşturulan "ihtiyaç karşılayan", "enerji kaynağı", "gerçek yaşam deneyimi" ve "vazgeçilmez bir öğe" kategorileriyle benzerlik göstermektedir. Yine, Güven ve Güven (2009) tarafından gerçekleştirilen araştırmada, kimi ilköğretim öğrencilerinin Sosyal Bilgiler dersine ilişkin olumsuz düşüncelere sahip oldukları sonucuna ulaşılmıştır. Bu sonuç, araştırmada Hayat Bilgisi dersine ilişkin üretilen metaforlara dayalı olarak oluşturan "olumsuz etki" kategorisiyle benzerlik göstermektedir. Araştırma kapsamında oluşturulan "gerçek yaşam deneyimi" ve "vazgeçilmez bir öğe" kategorileri, Aydın ve Eser-Ünaldı́nın (2010) Coğrafya dersine yönelik üretilen metaforları ortaya koymayı amaçlayan araştırmasındaki "yaşamın ifadesi olarak Coğrafya" ve "önemin ifadesi olarak Coğrafya" kategorileriyle benzerlik göstermektedir. Ayrıca, Yaşar ve Gürdoğan Bayır (2010) tarafından yapılan araştırmada Sosyal Bilgiler dersine ilişkin oluşturulan "farklı konuların birleşimi olarak Sosyal Bilgiler" kategorisi, bu araştırmada oluşturulan "geniş bir içerik" kategorisiyle benzerlik göstermektedir. Her iki çalışmada da farklı konuların ele alındığını anlatan dünya metaforunun ortak olduğu görülmüştür.

Hayat Bilgisi dersi, en genel anlamıyla, öğrenciyi yaşama hazırlar. Öğrencinin sosyal yaşamda kendini ifade edebilmesine olanak sağlayacak kimi bilgi, beceri ve tutumları edinmesini amaçlar. Bu açıdan bakıldığında araştırmada elde edilen bulguların Hayat Bilgisi dersinin amaçlarıyla örtüştüğü söylenebilir. Öğretmen adaylarının Hayat Bilgisi dersini önemli ve gerekli olduğunu belirtmeleri, güncel yaşamla ilişkili, ilgi çekici ve yaşama hazırlamada yönlendirici bir ders olarak görmeleri, bu dersin ne kadar önemli bir ders olduğunun da kanıtı olarak görülebilir. Bu noktada araştırma bulgularının, Hayat Bilgisi dersinin önemine dikkat çekeceği düşünülmektedir. Öğretmen adaylarının Hayat Bilgisi dersine ilişkin algıları, bu dersin öğretiminin iyileştirilmesine yönelik de ipuçları içermektedir. Öğretmen adaylarının bu dersi sorun çözücü, hem içerik hem de öteki dersler açısından birbirileriyle bağlantılı ve yaşama hazırlamada yönlendirici bir ders olarak görmeleri, mesleğe başladıklarında sınıf içi uygulamalarına da yansıyacaktır. $\mathrm{Bu}$ dersin öneminin ve kazandırdıklarının farkında olan bir öğretmen de etkili öğretimin gerçekleştirilmesine olanak sağlayacaktır. Araştırma bulgularına bakıldığında öğretmen adaylarııı Hayat Bilgisi dersini farkındalık kazanma ile ilişkilendirdikleri görülmektedir. Kendi yaşamı ve öğrenme sürecine ilişkin farkındalık kazanan, başka bir deyişle, kendi öğrenme sorumluluğunun farkında olan bireyler yapılandırmacı öğrenme ortamlarında yetiştirilmesi hedeflenen birey özelliklerini yansıtır. Tüm bunların yanı sıra, araştırma sonuçlarına göre Hayat Bilgisi dersine ilişkin olumsuz algıya sahip öğretmen adaylarının olduğu ortaya çıkmışır. Bu bağlamda olumsuz düşüncelerin nedenlerini ortaya çıkarmayı amaçlayan araştırmalara gereksinim duyulmaktadır.

Araştırmadan elde edilen bu bulgular bağlamında şu öneriler getirilebilir:

- Hayat Bilgisi dersine yönelik algılar değişik yöntemlerle de belirlenebilir. Bu araştırmalar, Hayat Bilgisi dersinin önemine dikkat çekecektir. 
- Öğretmenlerin öğretme-öğrenme sürecinde öğrenci gereksinimlerini belirlemede metaforları kullanmaları etkili olabilir. Buna ilişkin öğretmenlere rehberlik edilebilir.

- Sınıf öğretmeni adaylarının, Hayat Bilgisi dersine ilişkin olumsuz algılarının nedenleri araştıılabilir ve bu olumsuzluğu gidermek için önlemler alınabilir.

- Sınıf öğretmeni adaylarının Hayat Bilgisi dersi dışında diğer derslere ilişkin sahip oldukları metaforlar belirlenebilir.

\section{Kaynakça}

Alacapınar, F. (2011). İlköğretim okulu öğrencileri öğretmenlerini nelere benzetmektedirler?. Selçuk Üniversitesi Ahmet Keleşoğlu Eğitim Fakültesi Dergisi, 32, 249-263.

Aydın, F. \& Eser-Ünaldı, Ü. (2010). Coğrafya öğretmen adaylarının Coğrafya kavramına ilişkin algılarının metaforlar yardımıyla analizi. International Online Journal of Educational Sciences, 2(2), 600-622.

Aydın, i. S. \&Pehlivan, A. (2010). Türkçe öğretmeni adaylarının öğretmen ve öğrenci kavramlarına ilişkin kullandıkları metaforlar. Turkish Studies, 5(3), 818-842.

Aydoğdu, E. (2008). Ilköğretim okullarındaki öğrenci ve öğretmenlerin sahip oldukları okul algıları ile ideal okul algılarının metaforlar (mecazlar) yardımılla analizi. Unpublished master's thesis, Eskişehir Osmangazi Üniversitesi, Eskişehir, Turkey.

Büyüköztürk, Ş., Kılıç Çakmak, E., Akgün, Ö. E., Karadeniz, Ş. \& Demirel, F. (2012). Bilimsel araştırma yöntemleri. Ankara: Pegem Akademi.

Cerit, Y. (2008). Öğretmen kavramı ile ilgili metaforlara ilişkin öğrenci, öğretmen ve yöneticilerin görüşleri. Türk Eğitim Bilimleri Dergisi, 6(4), 693-712.

Cortazzi, M. \& Jin, L. (1999). Bridges to learning: Metaphors of teaching, learning and language. In L. Cameron ve G. Low (Eds.). Researching and applying metaphor (pp.149-176). Cambridge: Cambridge University Press.

Creswell, J. W. (2005). Educational research: Planning, conducting and evaluating quantitative and qualitative research. New Jersey: Pearson Education.

Çelikten, M. (2006). Kültür ve öğretmen metaforları. Sosyal Bilimler Enstitüsü Dergisi, 21(2), 269-283.

Girmen, P. (2007). Ilköğretim öğrencilerinin konuşma ve yazma sürecinde metaforlardan yararlanma durumları. Unpublished doctoral dissertation, Anadolu Üniversitesi, Eskişehir, Turkey.

Greves, S. V. (2005). Butterflies in our classrooms: Using metaphors in teacher educatiom. The Teacher Educator, 41(2), 95-109.

Güven, B. \& Güven, S. (2009). Illköğretim öğrencilerinin sosyal bilgiler dersinde metafor oluşturma becerilerine ilişkin nicel bir inceleme. Kastamonu Eğitim Dergisi, 17(2), 503-512.

Kılıç, F.D. \& Güven, B. (2009, May). Examining the metaphors students construct in life sciences lessons. Paper presented at the meeting of the First International Congress of Educational Research. Çanakkale Onsekiz Mart University, Çanakkale, Turkey.

Kövecses, Z. (2010). Metaphor: A practical introduction. Oxford: Oxford University Press.

Lakoff, G. \& Johnson, M. (2005). Metaforlar: Hayat, anlam ve dil. i̇stanbul: Paradigma Yayıncılık.

Saban, A. (2008). Okula ilişkin metaforlar. Kuram ve Uygulamada Eğitim Yönetimi, 55, 459-496.

Saban, A. (2009). Öğretmen adaylarının öğrenci kavramına ilişkin sahip oldukları zihinsel imgeler. Türk Eğitim Bilimleri Dergisi, 7(2), 281-326. 
Mehmet GÜLTEKIN ve Aslı GÜNDOĞAN ÇÖGENLi - Çukurova Üniversitesi Eğitim Fakültesi Dergisi, 43(1), 2014, 01-18

Taşdemir, M. \& Taşdemir, A. (2011, April). Ilköğretim programı üzerine öğretmen metaforları. Paper presented at the meeting of 2nd International Conference on New Trends in Education and Their Implications, Antalya, Turkey.

Yaşar, Ş. \& Gürdoğan Bayır, Ö. (2010). İlköğretim 5. sınıf öğrencilerinin bakış açısıyla sosyal bilgiler. EJournal of New World Sciences Academy, 5 (3).

Yıldırım, A. \& Şimşek, H. (2011). Sosyal bilimlerde nitel araştırma yöntemleri. Ankara: Seçkin Yayıncılık.

Yıldırım, A., Ünal, A. \& Çelik, M. (2011). Öğretmen kavramına ilişkin öğretmen, yönetici ve müfettiş algılarının analizi. Uluslararası Insan Bilimleri Dergisi, 8(2), 92-109.

Zanotto, M. S., Cameron, L. \& Cavalcanti, M. C. (2008). Confronting metaphor in use: An Applied linguistic approach. Amsterdam: John Benjamins Publishing Company. 